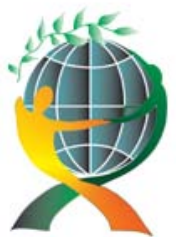

\author{
(online) $=$ ISSN $2285-3642$ \\ ISSN-L = $2285-3642$ \\ Journal of Economic Development, Environment and People \\ Volume 9, Issue 3, 2020
}

URL: http://jedep.spiruharet.ro

e-mail: office_jedep@spiruharet.ro

\title{
Circular Economy can Provide a Sustainable Global Society
}

\author{
Haradhan Kumar MOHAJAN ${ }^{1}$ \\ Assistant Professor, Department of Mathematics, Premier University, Chittagong, Bangladesh
}

\begin{abstract}
Since the start of the Industrial Revolution about 260 years ago, the negative effects of the traditional linear economy (LE) have become a threat to the stability of the economies and natural ecosystems. The strength of climate change, reduction of environmental pollution, and integrity of ecosystems are essential issues for the survival of global humanity. According to LE resources for production are easily available and unlimited, and after use wastes are disposable. The circular economy (CE) is an alternative to the LE where the resources may be used for as long as possible. It tries to capture the value of existing products and materials and decreases the use of primary materials in industries. The CE is a part of environmental economics and beneficial to society. It keeps products, components, and materials at their highest utility and maximum value at all times. At present, CE is one of the most focused terms among environmental economic scientists. The aim of this study is the implementation of sustainable development strategies and the transition from $L E$ towards $C E$.
\end{abstract}

Keywords: Circular economy, Economic growth, Recycling, Reuse, Reduction, Sustainable development, SWOT analysis.

JEL Codes: A1, O1, P2

How to cite: Mohajan, H. K. (2020). Circular Economy can Provide a Sustainable Global Society. Journal of Economic Development, Environment, and People, 9(3), pp. 38-62. DOI: https://doi.org/10.26458/iedep.v9i3.670

\section{Introduction}

Recently global production and consumption of various commodities have increased due to the rising of the global population and economic development. As a result, environmental pollution increases alarmingly. The circular economy (CE) substantially can reduce environmental pollution. It is an economic system that rethinks to use raw materials and resources for the creation of a sustainable economy; free of waste and emissions. It converts waste into valuable resources in the economy. The CE mainly emerges from 3R's principles: Reduction, Reuse, and Recycle [Preston, 2012]. It means shifting from the traditional unsustainable linear economy (LE) (Figure 1) of "take, make, waste" (i.e., goods are manufactured from raw materials, sold, used, and then incinerated or discarded as waste) to a

\footnotetext{
${ }^{1}$ Corresponding author email: Email: haradhan1971@gmail.com, mobile phone : +8801716397232
} 


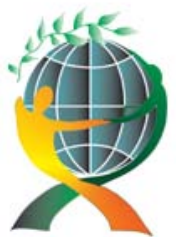

\author{
(online) $=$ ISSN $2285-3642$ \\ ISSN-L = $2285-3642$ \\ Journal of Economic Development, Environment and People \\ Volume 9 , Issue 3, 2020
}

URL: http://jedep.spiruharet.ro

e-mail: office jedep@spiruharet.ro

sustainable economy (Figure 2) of "reduce, reuse, recycle". It is an industrial system that restores renewable energy and eliminates toxic chemicals and wastes from the environment. Recently CE attracted increased attention to the major global companies, policymakers and environment economic scientists [Ellen MacArthur Foundation, EMF, 2013]. According to CE "Nothing is lost, everything is transformed" [Alexandru \& Taşnadi, 2014].

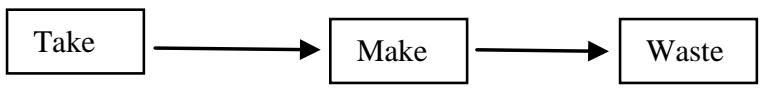

Figure 1: Linear economy. Source: [EMF, 2016].

Actually, CE cannot ensure 100\% implementation of 3R's principles in society (Andersen, 2007). Everything as much as possible is reused, remanufactured, and recycled back into raw material and used as a source of energy. The negative effects of waste are threatening to economies and ecosystems [Park \& Chertow, 2014]. The CE also requires water and energy to come from renewable resources and that biological material, such as food wastes, are returned to the soil [Natural Scotland, 2013].

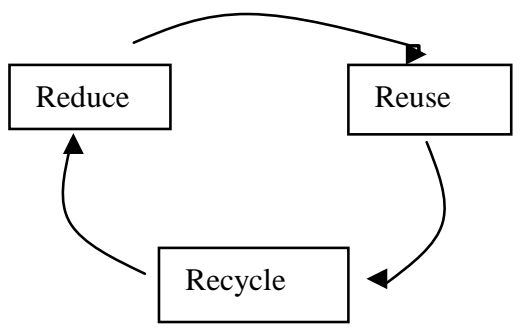

Figure 2: Circular economy. Source: [EMF, 2016].

The CE can be classified into upcycling and downcycling [Cullen, 2017]. Upcycling (creative reuse) refers to converting waste material into something of better quality or better environmental value [Sung et al., 2014; Braungart et al., 2014]. For example, the conversion of waste plastics into carbon nanotubes, such as graphene indicates upcycling [Zhuo \& Levendis, 2013]. On the other hand, downcycling indicates that materials are recovered and converted into materials of lesser quality. For example, i) a plastic computer case conversion into a plastic cup, which then becomes a park bench, and ii) steel scrap from end-of-life vehicles are often contaminated with copper from wires and tin from coating becomes lower quality steel and mostly applied in the construction sector indicate downcycling [Cullen et al., 2012]. The terms upcycling and downcycling were first used by Reiner Pilz in an interview by Thornton Kay in SalvoNEWS in 1994 [Kay, 1994]. Downcycling can help to keep materials in use, 


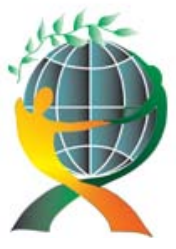

\author{
(online) $=$ ISSN $2285-3642$ \\ ISSN-L = $2285-3642$ \\ Journal of Economic Development, Environment and People \\ Volume 9, Issue 3, 2020 \\ URL: http://jedep.spiruharet.ro \\ e-mail: office jedep@spiruharet.ro
}

reduce consumption of raw materials, and avoid the energy usage, greenhouse gas (GHG) emissions, air pollution, and water pollution of primary production and resource extraction [Pires et al., 2019].

The transition to $\mathrm{CE}$ does not only amount to adjustments aimed at reducing the negative impacts of the LE, but also reflects a systemic shift that builds long-term resilience, generates business and economic opportunities, and provides environmental and societal benefits [EMF, 2013]. Recently urbanization, industrialization, and globalization have increased globally. More than two-thirds of the world's energy is consumed in cities. Various activities of cities emit more than $70 \%$ of global $\mathrm{CO}_{2}$. Between 1900 and 2015, the urbanized population increased from $14 \%$ to $54 \%$. The natural extraction of resources has increased 12 -fold between 1900 and 2015. The global materials use has increased from 26.7 billion tons in 1970 to 84.4 billion tons in 2015, and it is expected to be about 184 billion tons by 2050 [Circle Economy, 2019].

During the last five decades, the global population, food production, and energy consumption have increased approximately 2.5 -fold, 3-fold, and 5-fold, respectively. Global material extraction became more than doubled from 36 billion tones in 1980 to 85 billion tones in 2013. Human activities are already affecting climate change, biodiversity, biogeochemical flows, and land system [Mohajan, 2015; Steffen et al., 2015]. The CE ensures renewable, reusable, and non-toxic resources to utilize materials and energy in an efficient way that provides economic, environmental, and societal benefits. It causes gradually decoupling economic activity from the consumption of finite resources and designing waste out of the system [Geissdoerfer et al., 2017]. It aims to keep products, components, and materials at their highest utility and value at all times to keep resources in use for as long as possible, extracting the maximum value from them whilst in use, and recovering and regenerating products and materials at the end of their service life [Benton \& Hazell, 2013].

Since the Industrial Revolution humankind has been using raw materials for the production and consumption of goods and wastes are unconsciously discarded [Mohajan, 2019b, 2020]. The CE is an industrial model that is regenerative by intention and design and aims to improve the performance of resources. It offers a new chance of innovation and integration between natural ecosystems, businesses, our daily lives, and waste management [EMF, 2014]. The world population and middle classes in every nation are increasing very rapidly, the total demand for materials is increasing in parallel. To feed the global population, about $60-70 \%$ more food will be needed by 2050 , redesigning our economy and protecting and regenerating biological systems can meet these challenges that are provided by CE. So CE is necessary, as it leads to lower material needs [EMF, 2012].

To achieve CE, recycling, efficient use of resources, refurbishment and reuse of products and components, utilization of renewable energy sources, remanufacturing, product life extension, product sharing, and waste prevention are needed [Rizos et al., 2017].

\title{
2. Literature Review
}

Kenneth E. Boulding claimed that circular systems within the global economy are unavoidable in order to guarantee human life on the earth in the long run [Boulding, 1966]. David W. Pearce and R. 


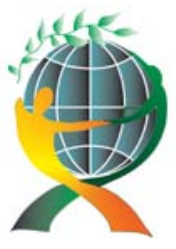

\author{
(online) $=$ ISSN $2285-3642$ \\ ISSN-L = $2285-3642$ \\ Journal of Economic Development, Environment and People \\ Volume 9 , Issue 3, 2020
}

URL: http://jedep.spiruharet.ro

e-mail: office jedep@spiruharet.ro

Kerry Turner agreed that the traditional LE without recycling elements cannot be sustainable and consequently must be replaced by a circular system [Pearce \& Turner, 1989]. According to Robert Meril, Michele Preziosi, and Alessia Acampora CE is a concept that shares many common principles of recycling with others which are beneficial to society [Merli et al., 2017]. Walter R. Stahel and Genevieve Reday conceptualized a loop economy to describe industrial strategies for waste prevention, regional job creation, resource efficiency, and dematerialization of the industrial economy [Stahel \& Reday, 1976].

Sylvie Geisendorf and Felicitas Pietrulla propose a revised definition of the CE after having analyzed and compared the most prominent related concepts [Geisendorf, \& Pietrulla, 2018]. The Ellen MacArthur Foundation, a nonprofit organization, developed the refinement and development of the concept of CE as a regenerative design, performance economy, cradle to cradle, biomimicry, and blue economy. According to it, $\mathrm{CE}$ is the transformation and use of natural resources in such a manner as to maintain and preserve the ecologic equilibrium and economic growth [EMF, 2013]. In a review paper Patrizia Ghisellini, Catia Cialani, and Sergio Ulgiati have discussed the origins, basic principles, advantages and disadvantages, modeling, and implementation of CE globally [Ghisellini et al., 2016].

Mikael Skou Andersen realizes that CE provides a beneficial and inclusive economy by focusing on minimizing resource consumption and waste disposal (Andersen, 2007). Shan Zhong and Joshua Pearce stress on enhancing the CE in plastic recycling. According to them, plastic waste is upcycled into 3-D printing filament with a recycle bot, which is an open-source waste plastic extruder. This process benefits the environment and sustainability as well as the economic stability of consumers [Zhong \& Pearce, 2018]. William McDonough and Michael Braungart for a new way of designing our material goods and for going beyond the concept of eco-efficiency which only focuses on reducing the negative impacts of human activity on the environment [McDonough \& Braungart, 2002]. Felix Preston suggested that industrialized nations and companies must take several practical steps, such as best practice and knowledge sharing, smart regulation, standardization, raising public awareness, and support for the development of nations in pursuit of CE [Preston, 2012].

Luc Alaerts and his coauthors briefly discuss the monitoring frameworks based on macro indicators that summarize the progress at the national level, and micro indicators tailored towards assessing circularity at the level of products. They have developed a conceptual approach that aims to bridge the gap between the micro and macro level with meso level indicators [Alaerts et al., 2019]. Marco Pesce and his coauthors have discussed SWOT analysis and implementation principles of CE sustainability practices in companies, different industries, and territories for the development of the green energy industry in China [Pesce et al., 2020].

World Health Organization (WHO) shows that the transition to a CE provides a major opportunity to obtain substantial health benefits. It also identified the risks of adverse and unintended health effects in processes involving hazardous materials during the implementation of CE [WHO, 2018]. Vasileios Rizos, Katja Tuokko, and Arno Behrens developed a framework consists of eight main processes of the CE: i) recycling, ii) efficient use of resources, iii) utilization of renewable energy sources, iv) remanufacturing, 


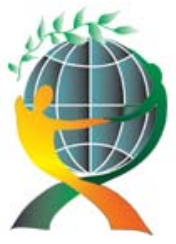

\author{
(online) $=$ ISSN $2285-3642$ \\ ISSN-L = $2285-3642$ \\ Journal of Economic Development, Environment and People \\ Volume 9, Issue 3, 2020 \\ URL: http://jedep.spiruharet.ro \\ e-mail: office_jedep@spiruharet.ro
}

refurbishment and reuse of products, and components, v) product life extension, vi) product as a service, vii) sharing models, and viii) a shift in consumption patterns [Rizos et al., 2017].

\title{
3. Methodology of the Study
}

Research methodology indicates the logic of development of the process used to generate theory that is the procedural framework within which the research is conducted [Remenyi et al., 1998]. It provides us the principles for organizing, planning, designing, and conducting good research. Hence, it is the science and philosophy behind all researches [Legesse, 2014]. The methodology of this article is to discuss CE in some details. A linear economy is a one-directional economy where produced materials become wastes after consumption which is sometimes called "cradle to grave" economy. On the other hand, the circular economy is sometimes called "cradle to cradle" economy. Source of CE are from 3R's principles: Reduction, Reuse, and Recycle [Preston, 2012].

The CE becomes essential for sustainable economic development and the welfare of global humanity. In this study, secondary data are used to develop this article. For the collection of secondary data we have used both published and unpublished data sources. The published data are collected from: i) national and international journals, ii) various publications of foreign governments or international bodies and their subsidiary organizations, iii) various research reports of research scholars, iv) books of famous authors, research notebooks, handbooks, theses, magazines, and newspapers, v) websites, and vi) public records and statistics, historical documents, and other sources of published information. The unpublished data are collected from diaries, letters, unpublished biographies and autobiographies, and also from scholars and research workers, trade associations, and other public/private individuals and organizations.

\section{Objective of the Study}

The main objective of this study is to represent the aspects of CE against the traditional LE. It also will be carried out under the following specific objectives:

- To provide a basic understanding of CE.

- To show the procedure of CE among different nations.

- To highlight different levels of CE.

- To describe in brief benefits, importance, and barriers of CE, and its SWOT analysis.

\section{Concepts of CE}

The CE in area development is still in its infancy. It is considered a possible solution to mitigate problems, such as the increasing global demand for resources, climate change, and worldwide pollution. 


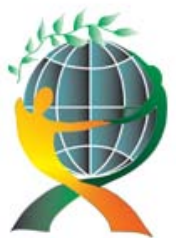

\author{
(online) $=$ ISSN $2285-3642$ \\ ISSN-L = $2285-3642$ \\ Journal of Economic Development, Environment and People \\ Volume 9 , Issue 3, 2020
}

URL: http://jedep.spiruharet.ro

e-mail: office jedep@spiruharet.ro

The CE has links to many of the 17 Sustainable Development Goals (SDGs), such as no poverty, responsible consumption and production, sustainable cities and communities, and the promotion of inclusive and sustainable industrialization and innovation, approved by the UN in 2015 [Berg et al., 2018]. The CE is a model of production and consumption, which involves sharing, renewing, leasing, reusing, repairing, dematerializing, upgrading, refurbishing, and recycling existing materials and products as long as possible. Recently CE became popular worldwide for sustainable economic development and to make a harmonious society [Naustdalslid, 2014].

There is no unequivocal definition of CE. There is a close link between the concepts of $\mathrm{CE}$ and sustainability [Whalen et al., 2018]. Julian Kirchherr, Denise Reike, and Marko Hekkert defined CE as, "The circular economy is an economic system based on business models that replace the concept of endof-life with reducing, reusing and recovering raw materials in production, distribution and consumption processes, by operating at different levels of scale and with the aim of achieving sustainable development for present and future generations" [Kirchherr et al., 2017]. The Ellen MacArthur Foundation defined the $\mathrm{CE}$ as, "A circular economy is one that is restorative and regenerative by design and aims to keep products, components, and materials at their highest utility and value at all times, distinguishing between technical and biological cycles" [EMF, 2016].

The Chinese CE promotion laws define CE as, "A generic term for the reducing, reusing and recycling activities conducted in the process of production, circulation, and consumption" [China Council for International Cooperation on Environment and Development, CCICED, 2008]. The World Economic Forum defined CE as, "A circular economy is an industrial system that is restorative or regenerative by intention and design. It replaces the end-of-life concept with restoration, shifts towards the use of renewable energy, eliminates the use of toxic chemicals, which impair reuse and return to the biosphere, and aims for the elimination of waste through the superior design of materials, products, systems and business models" [Schwab, 2019]. The EU Action Plan defined the CE as, "In a circular economy the value of products and materials is maintained for as long as possible; waste and resource use are minimized, and resources are kept within the economy when a product has reached the end of its life, to be used again and again to create further value" [European Commission, EC, 2015].

In a $\mathrm{CE}$, economic activity builds and rebuilds the overall system of a sustainable economy. The CE indicates the importance of the economy to work effectively in large and small businesses, organizations, and individuals locally and globally. The aim of CE is to less use of natural resources, reduction of pollution, tackle climate change, enhance consumer satisfaction, and improve the bottom line. It aims to design out waste. The products are designed and optimized for a cycle of disassembly and reuse. Biological ingredients are at least non-toxic and possibly even beneficial, and safely be returned to the biosphere. The energy required to fuel should be renewable by nature to decrease resource dependence and increase systems resilience [McDonough \& Braungart, 2002].

Other related approaches of CE are; cradle-to-cradle [McDonough \& Braungart, 2002; Bjorn \& Strandesen, 2011], symbiosis [Lombardi \& Laybourn, 2012], laws of ecology [Commoner, 1971], looped and performance economy [Stahel, 2010], blue economy [Pauli, 2010], closed-loop supply chains 


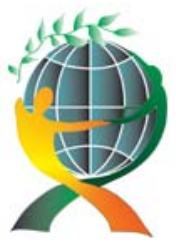

\author{
(online) $=$ ISSN $2285-3642$ \\ ISSN-L = $2285-3642$ \\ Journal of Economic Development, Environment and People \\ Volume 9, Issue 3, 2020 \\ URL: http://jedep.spiruharet.ro \\ e-mail: office jedep@spiruharet.ro
}

[Bhattacharjee \& Cruz, 2015], regenerative design [Lyle, 1994], natural capitalism [Hawken et al., 2000], industrial ecology, reverse logistics [Agrawal et al., 2015], resource efficiency [Birat, 2015], low waste production, biomimicry [Benyus, 1997], and sustainability [Charonis, 2012].

\title{
6. Origin of CE
}

The discourse on the CE originated in the early 1970s. Ecological economist Kenneth E. Boulding considered the economy as a closed and circular system with limited assimilative capacity for the maintenance of the sustainability of human life on the earth in the long run but he did not use the phrase 'circular economy'. He called the LE as a "cowboy economy" and proposed the "spaceman economy" for CE [Boulding, 1966]. In 1989, British environmental economists David W. Pearce and R. Kerry Turner primarily introduced the concept of a circular economic system depending on the studies of K. E. Boulding. According to them the traditional LE without recycling elements cannot be sustainable. They identified four economic functions of the environment as; i) provision of resources, ii) amenity values (e.g., the beauty of landscapes) iii) life support system, and iv) sink for waste and emissions [Pearce \& Turner, 1989].

Origins of CE are mainly rooted in ecological and environmental economics and industrial ecology. The essence of CE is found in General Systems Theory and Industrial Ecology (IE) [Preston, 2012; Ghisellini et al., 2016]. General Systems Theory supports holism, system thinking, complexity, organizational learning, and human resource development which are grounds of CE [Senge et al., 2010]. The elements of IE are the biological analogy, system perspectives, technological modifications, cooperation, dematerialization, eco-efficiency, and research and development [White, 1994]. The IE analyzes the industrial system and its environment as a joint ecosystem characterized by flows of more material, energy and information as well as by the provision of fewer resources and services from the biosphere [Erkman, 1997; Merli et al., 2017]. The CE promotes the transition from open to closed cycles of materials and energy, and leads to less wasteful industrial processes [Andersen, 2007]. The CE builds concepts on IE to analyze industrial systems operation and optimization to establish a new model of economic development, production, distribution and recovery of products [lung \& Levrat, 2014]. It is restorative on renewable energy to minimize, track, and eliminate the use of toxic chemicals and eradicate waste through careful design. It includes the activities of contribution to zero waste and keeping materials in use for as long as possible [EMF, 2014].

\section{Principles of CE}

The main principles of $\mathrm{CE}$ are "reduction, reuse and recycle". The reduction principle tries to minimize the input of primary energy, raw materials and waste through the improvement of efficiency in production and consumption processes that reduces resource and increases economic and social wellbeing. It promotes system effectiveness by revealing and designing out negative externalities [EMF, 2012; Su et al., 2013]. The reuse principle indicates to use resources again in production for the same 


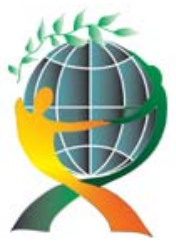

\author{
(online) $=$ ISSN $2285-3642$ \\ ISSN-L = $2285-3642$ \\ Journal of Economic Development, Environment and People \\ Volume 9 , Issue 3, 2020 \\ URL: http://jedep.spiruharet.ro \\ e-mail: office jedep@spiruharet.ro
}

purpose that provides environmental benefits as it requires fewer primary resources, less energy, and less labor, compared with the manufacture of new products. It preserves and enhances natural capital by controlling finite stocks and balancing renewable resource flows [EU, 2008; Castellani et al., 2015]. The recycle principle refers to reprocess waste materials into products that benefit the still usable resources and reduce the quantity of waste. It optimizes natural and manmade resources by circulating products, components, and materials [EU, 2008; Birat, 2015]. Some waste materials are recyclable for a limited time and some for unlimited times. For example, cellulose fibers may be recycled 4-6 times, but metals are recyclable unlimitedly [Reh, 2013].

The CE is based on the following three principles [EMF, 2012]:

i) Waste and pollutions are designed out. These indicate that the products of today can become the resources of tomorrow and the negative impacts of economic activity that cause damage to human health and natural systems must be eliminated. For example, the release of GHGs, the use of toxic and hazardous substances, the pollution of air, water, and land, incineration of waste, etc. are harmful to the environment. Hence waste and pollutions must be redesigned [EMF, 2013].

ii) Products and materials are kept in use. This includes favoring activities that increase product utilization and reuse to preserve embedded energy, labor, and materials. For example, designing for durability, repair, reuse, remanufacturing, and ultimately recycling of products and materials are necessary [EMF, 2014].

iii) Natural systems are regenerated. It involves, for example, deploying agricultural practices that not only avoid degrading soil but actually rebuild soil health over time [EMF, 2012].

The CE is founded in several principles as follows [EMF, 2012, 2013]:

Eco-design: It tries to reduce the environmental impacts throughout the life cycle of a product. It circulates products, components, and materials at their highest utility at all times, in both technical and biological cycles [Erkman, 2001].

Energy from renewable sources: It eliminates fossil fuels to produce the product, reuse, and recycle. It favors technologies and processes that use renewable or better performing resources [Geng et al., 2014].

Industrial and territorial ecology: It establishes an industrial-organizational method in a territory characterized by optimized management of finite stocks and balancing renewable flows of materials, energy, and services. The CE enhances natural capital by encouraging flows of nutrients within the system and creates the conditions for regeneration of soil and other living systems [Erkman, 1997; Preston, 2012].

Functionality economy: It aims to eliminate the sale of products in many cases to establish a system of a rental property [EMF, 2013].

Waste becomes a resource: All the biodegradable material returns to nature and the not biodegradable is reused. Resources, wastes, and byproducts of one company can become the inputs of another industrial process which reduces the use of raw materials, waste, and environment pollution [Frosch \& Gallopoulos, 1989]. 


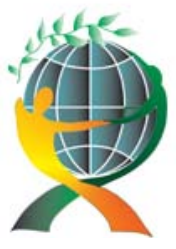

\author{
(online) $=$ ISSN $2285-3642$ \\ ISSN-L = $2285-3642$ \\ Journal of Economic Development, Environment and People \\ Volume 9, Issue 3, 2020 \\ URL: http://jedep.spiruharet.ro \\ e-mail: office_jedep@spiruharet.ro
}

Second use: It reintroduces in the economic circuit those products that no longer correspond to the initial consumers' needs [EMF, 2012].

Reuse: It reuses certain products or parts of those products that still work to elaborate on new artifacts [Geng et al., 2014].

Reparation: It finds damaged products a second life. It reveals and designs out negative externalities, such as land degradation, air, water, and noise pollution, the release of toxic substances, and GHG emissions [Steffen et al., 2015].

Recycle: It makes use of materials founded in waste [Preston, 2012].

Valorization: It harnesses energy from waste that cannot be recycled [Mirabella et al., 2014].

\title{
8. The CE Model
}

The CE predicts an economy that has no net effect on the environment, restoring any damage in resource acquisition and minimizing waste generation in manufacturing and the product life cycle [Murray et al., 2015]. The aim of CE is not proposing an absolute decrease in the levels of material use or a reduction in personal consumption levels, but continuing economic growth by utilizing resources more efficiently [Llanwarne, 2016].

The CE enables to create a circular supply chain in which residual outputs from one process feed into another process, to recover the resource value of materials in a manner that creates new value from these same materials, to extend the work-life of a product, and improve the usage rates of products through shared use [World Economic Forum, 2018].

The following models of $\mathrm{CE}$ are necessary to make the world sustainable for future generations [Accenture, 2015]:

Resource Recovery: This model enables a company to eliminate material leakage and maximize the economic value of product return flows. Recovery of useful resources/energy out of disposed of products [Accenture, 2015]. For example, the waste management company of Singapore, Tes-Amm connects seamlessly with its clients' manufacturing processes to help dispose of electronics scrap.

Circular Supplies: This model is based on supplying fully renewable, recyclable, or biodegradable resource inputs that strengthen circular production and consumption systems [Accenture, 2015]. For example, tire manufacturer Omni United in Singapore has tied up with US footwear company Timberland to make a special line of tires that can be easily recycled at the end of life into crumb rubber. The rubber is then used by Timberland for making shoe outsoles.

Product as a Service: This model offers an alternative to the traditional model of buy and own. Products are used by many customers through a lease or pay-for-use arrangement [Accenture, 2015]. For example, Sunlabob, a solar enterprise based out of Lao People's Democratic Republic (Lao PDR), has created a service-based approach to sustainable lighting in rural areas.

Product Life Extension: This model indicates to extend the working life cycle of products and components by repairing, upgrading, and reselling [Accenture, 2015]. For example, in Singapore, the Sustainable Manufacturing Centre and the Advanced Remanufacturing and Technology Centre have 


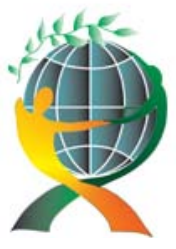

\author{
(online) $=$ ISSN $2285-3642$ \\ ISSN-L = $2285-3642$ \\ Journal of Economic Development, Environment and People \\ Volume 9 , Issue 3, 2020 \\ URL: http://jedep.spiruharet.ro \\ e-mail: office jedep@spiruharet.ro
}

been working with companies to improve the longevity of products through topics, such as green manufacturing, remanufacturing, repair and restoration, and product verification.

Sharing Platforms: This model promotes a platform for collaboration amongst product users, either individuals or organizations. It facilitates to increase the utilization rate of products by making possible shared use [Accenture, 2015]. For example, car-sharing is one of the earliest sharing platform models.

\title{
9. The Nations on the CE
}

In the last two decades, many countries of emerging economies have achieved impressive environmental improvements. But overproduction, consumption, and trade remain dangerously unstable globally yet [Preston, 2012].

Germany followed CE in early 1976 with the Waste Disposal Act. It implemented CE in 1996 accompanied by an enactment of a law: "Closed Substance Cycle and Waste Management Act" which provided for managing waste in a closed cycle and ensuring environmentally compatible waste disposal [Su et al., 2013]. In 2015, the European Commission announced a CE package that marks a milestone towards a modern conception of economic growth fit for the $21^{\text {st }}$ century [The Centre for European Policy Studies, CEPS, 2018].

Japan followed CE since 1991 with the Law for Effective Utilization of Recyclables and the Japanese CE initiative [The Institution of Environmental Sciences, IES, 2015]. In 2000, Japan became the second country that issued a law to promote CE nationally. The government tried its best to high production, high-consumption, and high waste into a "recycle-oriented society". It aimed to promote waste measures and recycle comprehensively and systematically [Zang, 2006].

The rapid economic development of China has increased wealth and has provided employment and business opportunities. The rapid economic growth pushed the country into serious natural resource depletion and environmental pollution. China is the third country engaged in serious efforts to implement CE on a large scale. China started CE in 1998 and the government of China (GoC) has accepted CE since 2002 [Yuan et al., 2006]. Initially, it likes to retain competitiveness and intends to introduce the CE framework on a smaller scale through several pilot studies so that it has a better basis for assessing its large scale and full coverage in the long run. This policy is like economic liberalization, which started with coastal free economic zones [Heshmati, 2015]. In 2009, China adopted "Circular Economy Promotion Law of the People's Republic of China" [Lieder \& Rashid, 2016]. Recently China strongly followed CE because of the huge problems on the environment and human health due to its very rapid and continuous economic development pattern. The CE is identified in China within the ecological economics framework. It introduced a new development model to help China leapfrog into a more sustainable economic structure [Su et al., 2013]. The CE emphasizes the benefits of reusing and recycling residual waste materials in energy, water, different byproducts, etc. For example, Dalian city in China is an important pilot study where the CE strategy was implemented during 2006-2010 [Park et al., 2010]. The concept of Chinese CE vibrates with the concept of IE which emphasizes the benefits of 


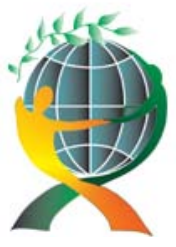

\author{
(online) $=$ ISSN $2285-3642$ \\ ISSN-L = $2285-3642$ \\ Journal of Economic Development, Environment and People \\ Volume 9, Issue 3, 2020 \\ URL: http://jedep.spiruharet.ro \\ e-mail: office jedep@spiruharet.ro
}

utilizing residual waste materials, including energy, water, different byproducts as well as information [Yuan et al., 2006].

The waste and resource sector in the UK has followed the recycling, composting, anaerobic digestion, etc. Therefore, other CE activities, such as repair, refurbishment, and remanufacturing are not followed significantly [Chartered Institution of Waste Management, 2014]. Recently, Europe is a pioneer when it comes to CE policy development. Many members of EU states including Finland, the Netherlands, Scotland, and France have launched CE strategies and initiatives [Sitra, 2016]. The USA partially adopted CE since the 1980 s as solid waste management, minimum content laws, labeling laws, selective landfill bans on specific materials, beverage containers recycling, and green labeling [He et al., 2013]. Very recently Australia and New Zealand are evaluating and accelerating an action agenda for the CE [Jewell, 2015]. A non-EU member state and a small economic power, Switzerland is trying to achieve CE policy at national and international levels [Alexandru \& Taşnadi, 2014].

\title{
10. Levels of CE
}

There is a three-layer approach to implement CE in the society: i) micro-level, ii) meso level, and iii) macro level. The CE can control production, consumption, and waste in these three levels. Recently China, Europe, Japan, the USA, and BRICS (Brazil, Russia, India, China, and South Africa) are substantially benefited from the partial implementation of CE.

\subsection{Micro Level}

The micro-level indicates the company or consumer level (single process). At this level, a company is either required or encouraged to conduct $\mathrm{CE}$ auditing. Here all enterprises are divided into five categories; green, blue, yellow, red, and black, according to their environmental performance. A company follows different strategies, such as production processes, green design, cleaner production (pollution prevention, toxic use reduction, and design for the environment), etc. to improve the circularity of its production system. It also cooperates with other companies over the supply chain to achieve a more effective circular pattern. They are encouraged to design more environmentally friendly products and adopt cleaner technology in their manufacturing processes [Yuan et al., 2006; Wrinkler, 2011].

Green consumption is an important policy that takes more environmentally friendly products and services. The green consumers' responsibility is to purchase and use of food, non-food sustainable products and services [European Commission, EC, 2010; Su et al., 2013]. The implementation of CE practices reverse supply chains and enables products at the end of their life cycle to reenter the supply chain as a production input through recycling, reusing, or remanufacturing [Genovese et al., 2017].

\subsection{Meso Level}




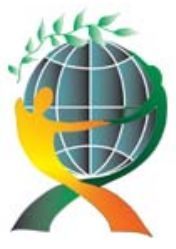

\author{
(online) $=$ ISSN $2285-3642$ \\ ISSN-L = $2285-3642$ \\ Journal of Economic Development, Environment and People \\ Volume 9 , Issue 3, 2020 \\ URL: http://jedep.spiruharet.ro \\ e-mail: office_jedep@spiruharet.ro
}

The meso level indicates the eco-industrial parks, industrial symbiosis districts, and networks [Su et al., 2013]. At this level, the main objective is to develop an eco-industrial network that will benefit both regional production systems and environmental protection. It monitors frameworks that report CE achievements in systems that fulfill the needs of society. The purpose of it is to achieve economic and environmental benefits [de Wit et al., 2018].

Industries work as separate entities and engage in complex interplays of resource exchange (material, water, energy, and byproducts) is called industrial symbiosis. The industrial ecology cares at all levels of analysis (facility level, inter-firm level, regional and global level). But the industrial symbiosis refers to the inter-firm level, as it involves physical exchanges among several organizations [Lowe et al., 1995; Chertow, 2000]. The international experiences of industrial symbiosis can be mainly traced back to both top-down (eco-industrial parks) and bottom-up (industrial symbiosis districts) strategies [Cutaia \& Morabito, 2012].

\title{
10.3. Macro Level
}

The macro-level indicates regions, provinces, cities, and nations. The CE development at the macro level can be formed by four systems as [Ness, 2008]: i) the industrial system, ii) the infrastructure system, iii) the cultural framework, and iv) the social system. The eco-city, eco-municipality, or ecoprovince is one of the most prominent environmental movements. The concept of eco-town was developed in the 1980s in the USA, and since 1997 a number of 26 eco-towns were created in Japan [van Berkel et al., 2009]. About 100 eco-cities were formed in Europe, such as in Germany, Sweden, and UK, and also in China [EU-ASIA, 2014; Marion, 2012].

Every year about 2.5 to 4 billion metric tons of wastes are collected worldwide and 1.3 billion tons of solid waste per year is generated in cities. Dangerous chemicals and metals, such as mercury, cadmium, lead, etc. are included in electrical and electronic wastes (e-wastes) and may leach into the environment and local ecosystem [Circle Economy, 2019].

\subsubsection{E-Wastes}

E-waste refers to all electronic equipment that has been discarded without the intent of reuse (Solving the e-Waste Problem, STEP Initiative, 2014). Recently e-waste is one of the fastest-growing waste flows in all nations. Production of e-waste increased from 20 million tons in 1998 to 41 million tons in 2010 globally [Kuehr, 2012]. In 2016, about 45 million tons of e-waste were produced worldwide, and only $20 \%$ of them were collected and recycled appropriately. By 2020 , e-waste from old computers in South Africa and China will have jumped by $200-400 \%$ and by $500 \%$ in India from 2007 levels [EMF, 2016].

\subsubsection{Plastics Waste}

Used plastic is considered as one of the elements of waste. More than the last 50 years plastics use has increased due to their versatility, low cost, and durability. Recently plastic has improved standards 


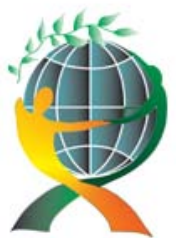

\author{
(online) $=$ ISSN $2285-3642$ \\ ISSN-L = $2285-3642$ \\ Journal of Economic Development, Environment and People \\ Volume 9, Issue 3, 2020 \\ URL: http://jedep.spiruharet.ro \\ e-mail: office jedep@spiruharet.ro
}

of living of the people [Shen et al., 2009]. Between 1964 and 2015 the production of plastics increased by more than twenty-fold. In 2015, the global plastic production was 322 million tons; roughly twothirds of which were contributed jointly by China (23\%), EU (21\%), the USA (16\%), and Japan (5\%). The production is growing by $3.86 \%$ per annum and is expected to increase by about 850 million tons per year by 2050 [Gu \& Togay, 2016].

Plastic is used in many sectors, such as packaging, baggage, financial transactions (Debit/Credit cards, plastic money), food containers, stationery items, toys, shoes, storage, electrical and electronic goods, household appliances, construction, automotive manufacture, furniture, agriculture, etc. In the beginning, it was mostly produced in Europe and the USA, but recently China became the leading producer with $28 \%$ of global production, and Japan $21 \%$ [Gopal et al., 2014].

About 4,900 million tons of the estimated 6,300 million tons totals of plastics ever produced have been discarded either in landfills or elsewhere in the environment. Plastics usually need more than 20 to 500 years to break down in landfills; incineration of plastic emits large quantities of harmful compounds and GHGs [Tansel \& Yildiz, 2011].

Plastic production is highly dependent on natural gas and oil (6\% of global oil). It takes about 185 liters of water to make one $\mathrm{kg}$ of plastic. Some plastics contain toxic chemical additives, including persistent organic pollutants (POPs), which have been linked to health issues, such as cancer, mental, reproductive, and developmental diseases. Plastic is also harmful to the environment, such as climate change, marine pollution, biodiversity, and chemical contamination [Barra \& Leonard, 2018].

A new plastic recycling 3-D printing filament with a recycle bot can recycle waste plastic, and then the postconsumer plastics can be turned into useful and more valuable products. 3-D print-based manufacture can save materials, reduce energy consumption, and decrease GHG emissions [Baechler et al., 2014; Redlich \& Moritz, 2016]. In 2011, recycling rate were 78\% in Japan, 59\% in EU, 48\% in China, and $8 \%$ in the USA [Zhuo \& Levendis, 2013].

It is estimated that only $9 \%$ of the 6,300 tons of plastic waste generated between 1950 and 2015 were recycled. India has probably the highest plastic recycling rate with estimates ranging from 47 to $60 \%$ [Plastic Europe, 2016]. Waste management policy is crucial for the $\mathrm{CE}$, so that the best overall environmental outcome is obtained.

\title{
11. Business Facilities in CE
}

Recently global resources and the climate faced heavy pressures due to human activities and CE can help to reduce these global sustainability pressures [Intergovernmental Panel on Climate Change, IPCC, 2014; EMF, 2014]. The CE activities, such as boosting recycling, save valuable materials, create new jobs, develop expertise, enhance eco-design, move towards zero-waste, reduce GHG emissions, etc. As a result, global business can improve smoothly [EC, 2014]. The CE can create a new business that is expected to lead to more sustainable development and a harmonious society [Mathews \& Tan, 2011]. It can create more appropriate and environmentally sound use of resources that can develop a new business model and innovative employment opportunities by implementing a greener economy [EMF, 


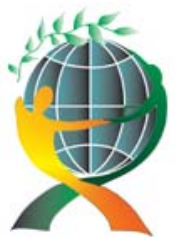

\author{
(online) $=$ ISSN $2285-3642$ \\ ISSN-L = $2285-3642$ \\ Journal of Economic Development, Environment and People \\ Volume 9 , Issue 3, 2020 \\ URL: http://jedep.spiruharet.ro \\ e-mail: office jedep@spiruharet.ro
}

2012]. It reduces material costs and diminishes resource dependence, and saves billions of dollars [Sariatli, 2017].

\title{
12. Effects of Knowledge Sharing in CE
}

The CE enhances natural capital, optimizes total resources, and minimizes system risks by the efficient management of finite stocks and renewable flows [de Man \& Friege, 2016]. Knowledge (explicit and tacit) sharing (KS) in CE can enhance the global sustainable economic development. The CE can save massive costs of production by recycling the wastes. Social innovation associated with sharing, ecodesign, reuse and recycling can create sustainable consumer behavior and improve human health, and KS can increase the CE more rapidly. Public awareness on negative effects of waste (e.g., open dumping, littering and waste segregation) can expand among mass people with the help of KS [Wysokinska, 2016; Mohajan, 2019a].

$\mathrm{KS}$ is essential for every company and every industry to face the global economic competition. It also can improve the principles of CE. Germany, China, Japan, BRICS, and other nations who initiated CE must share knowledge among them and with other nations to implement CE globally.

\section{SWOT Analysis for CE}

SWOT is an acronym of strengths, weaknesses, opportunities, and threats. It is a tool used by companies to understand and improve their operations. It is a scientific analysis method that combines the internal resources and external environment of a company or an organization. It helps the companies to face the current challenges efficiently and discover new technologies to develop them. To survive in a competitive market a company has to handle different internal and external strategies and SWOT analysis can help in this regard. Of the four branches of SWOT analysis; strengths and weaknesses are internal factors, and opportunities and threats are external factors [Humphrey, 2005].

There are enormous benefits or strengths and opportunities of CE but, it also has huge challenges, such as weaknesses and threats. The CE reduces wastes, recyclables resources, increases profit, creates new jobs, provides a sustainable environment, etc. On the other hand, it is quite an infancy and has to pass a thorny way. Governments spend a minimum amount for the implementation of CE. More campaigns, R\&D, and collection of capital are needed to implement CE in society. The SWOT analysis of CE is given as follows [Sariatli, 2017; Pesce et al., 2020]:

Strengths: These are positive internal factors to the organizations, which are favorable quantities to the management and performance of a company. Strengths of CE are:

- using the R\&D activities in CE a company can produce higher quality and more durable articles,

- proper guidance, principle, target, and strategy can implement CE into the organizations,

- proper waste management policies can enhance the CE in all nations,

- elimination of municipal wastes CE can present a cleaner environment, 


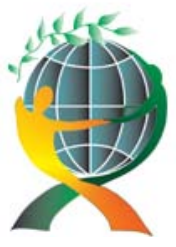

\author{
(online) $=$ ISSN $2285-3642$ \\ ISSN-L = $2285-3642$ \\ Journal of Economic Development, Environment and People \\ Volume 9, Issue 3, 2020 \\ URL: http://jedep.spiruharet.ro \\ e-mail: office jedep@spiruharet.ro
}

- innovation can help organizations to find new opportunities by studying both internal and external factors,

- due to the closed-loop processes, price fluctuations of the materials can be stabilized,

- there are many scopes for the involvement of experts and experienced people in CE projects,

- reinforces leadership and motivates the implementation of $\mathrm{CE}$,

- CE can reduce the use of raw materials and can present a sustainable society, and

- it reduces the risk for an organization if it operates in the wrong way.

Weaknesses: These are negative internal factors to the organizations that work against the development of functioning management practices and the performance of a company. Weaknesses of CE are:

- no precise guidelines and management system for implementation of CE are given yet,

- depends on the availability of information (e.g., sustainability-related, safety-related, CE-related, end-of-life-related information),

- there is still no internationally recognized standards institution to regulate the $\mathrm{CE}$,

- lack of guided processes for improving stewardship,

- employees have limited knowledge to run the CE activities efficiently,

- there is a gap between theory and practice,

- knowledge of CE is not efficiently transformed to common people,

- lack of knowledge on how to implement transparency,

- social marketing campaigns are not sufficient to develop $\mathrm{CE}$,

- lack of methods to implement systems thinking in a profitable way,

- highly dependent on top management's decision-making,

- investments and supports, such as money, human resources, training, and attention from management team are not enough to implement CE in all sectors, and

- if organizations face uncertainty about their activities and decisions with a wider sense, it will be difficult to implement CE.

Opportunities: These are positive external factors to the organizations, which implement the principles that can bring fortune to the company. Opportunities of CE are:

- CE can reduce the use of raw materials in industries during the production and can save costs,

- CE can strengthen relationships with stakeholders, such as the public, government, and customer,

- CE can inspire organization in the search for technological innovation and implementation of new tools to enhance competitiveness,

- By the use of upcycling technologies in CE we can develop our economies and can reduce environment pollutions,

- By the development of CE we can achieve business opportunities globally,

- CE can create a business opportunity for the entrepreneurs, 


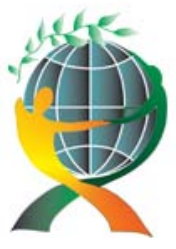

\author{
(online) $=$ ISSN $2285-3642$ \\ ISSN-L = $2285-3642$ \\ Journal of Economic Development, Environment and People \\ Volume 9 , Issue 3, 2020 \\ URL: http://jedep.spiruharet.ro \\ e-mail: office jedep@spiruharet.ro
}

- it can lead the management team to support and improve management processes, and

- it can improve internal performance, such as leadership, teamwork, work efficiency, etc.

Threats: These are negative external factors to the organizations, which are harmful to the existing principles of the company that have taken into consideration. Threats of CE are:

- the projects may lose the fast-changing market due to rapid competition,

- if companies control the entire life cycle then prices of products will increase and CE cannot be applied properly,

- innovative ideas could be easily copied by other competitors,

- financial disruptions in the CE can cause unpleasant outcomes,

- if it becomes difficult to benefit from waste management, CE processes can be abandoned,

- projects may abandon due to incapable of efficient staff turnover,

- In the beginning, CE cannot bring enough economic benefit to meet the business expectations,

- if labor cost increases companies can fail,

- modernization of CE may not bring enough economic benefits, and

- it is difficult to manage the use of products at end-of-life if the customers have a lack of education on how to use and dispose of them.

\title{
14. Benefits and Importance of CE
}

A CE has possible benefits in terms of competitive advantage, employment, waste reduction, and environmental protection [Llanwarne, 2016]. The CE promotes more appropriate and environmentally sound use of resources aimed at the implementation of a greener economy, characterized by a new business model and innovative employment opportunities. The CE favors activities that preserve value in the form of energy, labor, and materials [EMF, 2012]. By conserving materials of high-value products and high-quality secondary raw materials; CE would reduce demand for primary raw materials. At present the existing technology has a maximum potential of CE strategy is estimated to be $10-17 \%$ [EC, 2011].

More regenerative farming practices, such as organic farming, closing nutrient loops and reducing food waste in the food sector; factory-based industrial processes, smart urban planning, sharing of residential and office space, and energy-efficient buildings in construction, more sharing of cars, and better integration of different transport modes in mobility can implement CE in the society [EMF and McKinsey Center for Business and Environment, 2015].

A CE reveals and designs out the negative impacts of economic activity that causes damages to human health and natural systems. It decreases the negative externalities; optimizes agricultural productivity, measures waste prevention and eco-design and reuses of raw materials by reducing GHG emissions and hazardous substances. For example, emissions from industry in the EU would fall about $56 \%$ by 2050 if the CE is to become a reality [European Union, 2013]. The European Commission estimates that different combinations of more ambitious targets for recycling of municipal and 


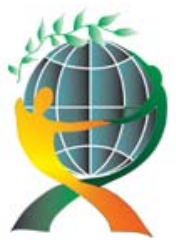

\author{
(online) $=$ ISSN $2285-3642$ \\ ISSN-L = $2285-3642$ \\ Journal of Economic Development, Environment and People \\ Volume 9, Issue 3, 2020
}

URL: http://jedep.spiruharet.ro

e-mail: office jedep@spiruharet.ro

packaging waste and reducing landfill could lead to a reduction in GHG emissions of around 424-617 million tons (48\%) of $\mathrm{CO}_{2}$ equivalent over 2015-2035 [European Environmental Agency, EEA, 2016]. It is realized that if the EU manufacturing sector adopted CE business models, can save about $\$ 630$ billion per year by 2025 [EMF, 2012].

CE reduces waste, drives greater resource productivity, delivers a more competitive economy, better addresses emerging resource security/scarcity issues in the future, and helps to reduce the environmental impacts of production and consumption. It is estimated that CE for food could generate $\$ 2.7$ trillion in benefits annually for the society and the environment by averting an estimated 5 million deaths every year by 2050. The CE reduces energy intensity, material intensity, and dispersion of toxic substances; enhance the ability to recycle, increase service intensity, extend product durability, and maximize the use of renewable resources [EMF, 2013].

CE has benefits that are operational as well as strategic and brings together a huge potential for value creation in the economics, business, environment, and social spheres. The residues are seen as valuable and these are absorbed as much as possible in order to be reused in the process. Sharing, eco-design, reuse, and recycling can develop sustainable consumer behavior which is benevolent for human health [EEA, 2016]. The CE could provide significant cost savings for various industries. For example, food, beverages, textiles, and packaging can save $\$ 700$ billion per year globally. It can create an opportunity of $\$ 630$ billion a year for only a subset of the EU manufacturing sectors and also can create about 500,000 new jobs in the UK [EMF, 2013].

A CE avoids the use of non-renewable resources and preserves or enhances renewable ones. Application of CE in the agricultural system ensures that important nutrients are returned to the soil through anaerobic processes or composting that softens the exploitation of land and natural ecosystems. In this process, waste is returned to the soil and the soil gets healthier and more flexible which reduces the cost of fertilizer. Hence CE in farming is useful for both the soils and the economy [Ghisellini et al., 2016].

The development of CE model, together with new regulation and organization of the labor markets, can bring greater local employment in entry-level and semi-skilled jobs. For example, in recycling and repairing practices new designers and mechanical engineers can find new jobs, and in the new businesses employees are needed. Economies must be benefited from the CE by major net material savings, mitigation of volatility and supply risks, drivers for innovation and job creation, regeneration and improved land productivity, and a path to a strong economy [Cholifihani, 2018]. It promotes virgin material minimization and the adoption of cleaner technologies. For example, reuses and cycles of waste are profitable for the environment [Andersen, 1999].

In brief, some benefits of CE are as follows [EMF, 2012]:

- creation of new green industries and jobs,

- provision of more return and lower risk to investors,

- avoid environmental damage caused by resource extraction,

- reduction of raw materials reduces energy use and reduction of $\mathrm{CO}_{2}$ emissions, 


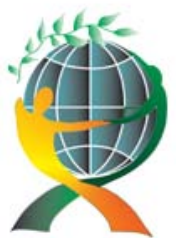

\author{
(online) $=$ ISSN $2285-3642$ \\ ISSN-L = 2285 - 3642 \\ Journal of Economic Development, Environment and People \\ Volume 9 , Issue 3, 2020 \\ URL: http://jedep.spiruharet.ro \\ e-mail: office jedep@spiruharet.ro
}

- save the business, customers, and suppliers money,

- less pollution enters in the earth's life support systems,

- use of renewable energy that in the long run is less polluting than fossil fuels,

- reuse and dematerialize of fewer materials and production processes are needed to provide good and functional products,

- energy-efficient and non-toxic materials and manufacture and recycle processes will be selected, and

- reduction in litter efficiently.

\title{
15. Barriers to Implement CE
}

The CE faces economic, social, and environmental challenges, such as resource-related challenges for businesses and economies [Preston, 2012]. There are many challenges in achieving high value, such as skills, training, and design implications in manufacturing [Llanwarne, 2016]. The main barriers in the CE are on technological, legal, economic, and behavioral levels. Technological barriers are the processes and technologies that are needed to establish closed loops and create technical and biological materials cycles. It is the need for changing and redesigning products and production systems. Legal barriers are the management of products, materials, and waste. Economic barriers are the complexities between regulations and business operations, international discrepancies, and outdated status of regulations. These are due to social and environmental externalities and are not considered in prices. Costs of raw materials are fickle and at low prices alternative, good quality secondary resources are not competitive, and the demand for circular products and alternatives is still small [Betchel et al., 2013].

Institutional barriers to CE are new business models that may be challenging to implement and develop because of laws and regulations. Many companies have short-term value creation goals and appraisal systems, whereas the CE is a long-term value creation model, the GDP index does not consider social and environmental externalities [EMF, 2014].

According to a Swedish study conducted in 2017 that the main five barriers to moving towards the CE are financial, structural, operational, attitudinal, and technological. Measuring of the financial benefits of CE and its profitability is a great challenge, the structural barrier is unclear within companies, the operational challenge is the difficulty of dealing and staying in control of processes within the valuechain, the attitudinal barrier is from the lack of knowledge about sustainability issues, and the technological barrier is the need for changing and redesigning products and production systems [van Ewijk, 2018].

Finally, a successful transformation to a circular model involves a new way of thinking, acting, plus communicating with others in the chain. However, an internal reluctance to move away from business as usual and to challenge current paradigms in a corporation is another risk [Rossi et al., 2016].

\section{Conclusions and Recommendations}




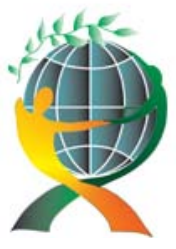

\author{
(online) $=$ ISSN $2285-3642$ \\ ISSN-L = $2285-3642$ \\ Journal of Economic Development, Environment and People \\ Volume 9, Issue 3, 2020 \\ URL: http://jedep.spiruharet.ro \\ e-mail: office_jedep@spiruharet.ro
}

In this study we have seen that the linear economy (take-make-dispose) is not sustainable for mankind. At the life end of a product if it is used again and again then economic value is created. We have observed that CE adds the value of a product as much as possible and tries to eliminate the waste. In CE waste of one process becomes the input for another process. In the study, we have tried to show the implementation of CE at various levels of companies and organizations. The CE has become a highprofile issue not only in developed countries but also in developing countries. After implementation CE will be beneficial to the society and economy as a whole. The CE can be developed by strengthening waste and e-waste management policies, establishing smart cities, improving public awareness, and participation in activities related to $\mathrm{CE}$.

In the $21^{\text {st }}$ century, the world faces serious environment pollutions and global climate change due to global warming. We have to improve the $3 R s$ in all sectors of every nation to implement CE in society. Europe, China, Japan, the USA, and some other nations are trying to implement CE in their own societies and globally. We have tried to discuss concepts, origin, principles, and models of CE. We further highlight business facilities and the effects of knowledge sharing in CE. The study also discusses the importance and benefits, barriers, and SWOT analysis of CE.

The study will help researchers, practitioners, environmental experts, and policymakers. From this study's future, researchers will find preliminary guidelines of CE. From the weak points of this study, they can criticize and develop the CE in their researches.

\title{
References
}

[1] Accenture Strategy (2015). Circular Advantage: An ASEAN Perspective-Innovative Business Models and Technologies to Create Value without Limits to Growth. Accenture Strategy.

[2] Agrawal, S., Singh, R. K., \& Murtaza, Q. (2015). A Literature Review and Perspectives in Reverse Logistics. Resources, Conservation and Recycling, 97, 76-92.

[3] Alaerts, L., Acker, K. V., Rousseau, S., Jaeger, S. D., Moraga, G., Dewulf, J., Meester, S. D., Passel, S. V., Compernolle, T., Bachus, K., Vrancken, K., \& Eyckmans, J. (2019). Towards a More Direct Policy Feedback in Circular Economy Monitoring Via a Societal Needs Perspective. Resources, Conservation \& Recycling, 149, 363-371.

[4] Andersen, M. S. (1999). Governance by Green Taxes: Implementing Clean Water Policies in Europe 1970-1990. Environmental Economy Policy Studies, 2(1), 3963. http://pure.au.dk/portal/files/12075926/Andersen Governance by green taxes.pdf

[5] Andersen, M. S. (2007). An Introductory Note on the Environmental Economics of the Circular Economy. Sustainable Science, 2(1), 133-140.

[6] Alexandru, I.-E., \& Taşnadi, A. (2014). From Circular Economy to Blue Economy, Management Strategies Journal, 26(4), 197-203.

[7] Baechler, C., DeVuono, M., \& Pearce J. M. (2013). Distributed Recycling of Waste Polymer into RepRap Feedstock. Rapid Prototyping Journal, 19(2), 118-125.

[8] Barra, R., \& Leonard, S. A. (2018). Plastics and the Circular Economy: A STAP Document. Scientific and Technical Advisory Panel (STAP) to the Global Environment Facility (GEF), UN Environment. 


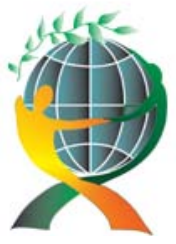

\author{
(online) $=$ ISSN $2285-3642$ \\ ISSN-L = $2285-3642$ \\ Journal of Economic Development, Environment and People \\ Volume 9 , Issue 3, 2020 \\ URL: http://jedep.spiruharet.ro \\ e-mail: office jedep@spiruharet.ro
}

[9] Benton, D., \& Hazell, J. (2013). Resource Resilient United Kingdom, a Report from the Circular Economy Task Force. London: Green Alliance.

[10] Benyus, J. M. (1997). Biomimicry. New York, NY: William Morrow.

[11] Berg, A., Antikainen, R., Hartikainen, E., Kauppi, S., Kautto, P., Lazarevic, D., Piesik, S., \& Saikku, L. (2018). Circular Economy for Sustainable Development. Reports of the Finnish Environment Institute, 26|2018.

[12] Betchel, N., Bojko, R., \& Volkel, R. (2013). Be in the Loop: Circular Economy \& Strategic Sustainable Development. Master's Degree Thesis, Blekinge Institute of Technology, Sweden.

[13] Bhattacharjee, S., \& Cruz, J. (2015). Economic Sustainability of Closed Loop Supply Chains: A Holistic Model for Decision and Policy Analysis. Decision Support Systems, 77, 67-86.

[14] Birat, J.-P. (2015). Life Cycle Assessment, Resource Efficiency and Recycling. Metallurgical Research \& Technology, 112 (206), 1-24.

[15] Bjorn, A., \& Strandesen, M. (2011). The Cradle to Cradle Concept: Is it always Sustainable? Poster Session Presented at the Life Cycle Management (LCM) Conference, Towards Life Cycle Sustainability Management, Berlin, Germany.

[16] Boulding, K. E. (1966). The Economy of the Coming Spaceship Earth. In H. Jarrett (Ed.), pp. 3-14. Environmental Quality Issues in a Growing Economy: Essays from the Sixth RFF Forum. Baltimore MD: John Hopkins University Press.

[17] Braungart, M., McDonough, W., \& Clinton, P. B. (2014). The Upcycle: Beyond Sustainability-Designing for Abundance. New York, Farrar, Straus and Giroux.

[18] Castellani, V., Sala, S., \& Mirabella, N. (2015). Beyond the Throwaway Society: A Life Cycle-Based Assessment of the Environmental Benefit of Reuse. Integrated Environmental Assessment and Management, 11(3), 373382.

[19] CCICED (2008). Circular Economy Promotion Law of the People's Republic of China. http://www.bjreview.com.cn/document/txt/2008-12/04/content_168428.htm

[20] CEPS (2018). The Role of Business in the Circular Economy Markets: Processes and Enabling Policies. Report of a CEPS Task Force. The Centre for European Policy Studies (CEPS), Brussels.

[21] Charonis, G. (2012). Degrowth, Steady State Economics and the Circular Economy: Three Distinct yet Increasingly Converging Alternative Discourses to Economic Growth for Achieving Environmental Sustainability and Social Equity. In World Economic Association Sustainability Conference 2012.

[22] Chartered Institution of Waste Management (2014). The Circular Economy: What Does it Mean for the Waste and Resource Management Sector? Northampton, UK: CIWM.

[23] Chertow, M. R. (2000). Industrial Symbiosis: Literature and Taxonomy. Annual Review of Energy and the Environment, 25, 313-337.

[24] Cholifihani, M. (2018). Mitigating the Adverse Impacts of the Circular Economy: Implementation and Role of Governments. In Venkatachalam Anbumozhi and F. Kimura (Eds.), Industry 4.0: Empowering ASEAN for the Circular Economy, pp. 261-283, Jakarta: ERIA.

[25] Circle Economy (2019). The Circular Gap Report 2019: Closing the Circularity Gap in a 9\% World. The Platform for Accelerating the Circular Economy (PACE). The Global Environment Facility and UN Environment. The World Economic Forum.

[26] Commoner, B. (1971). The Closing Circle: Nature, Man, and Technology. Random House, New York.

[27] Cullen, J. M. (2017). Circular Economy: Theoretical Benchmark or Perpetual Motion Machine? Journal of Industrial Ecology, 21(3), 483-486. 


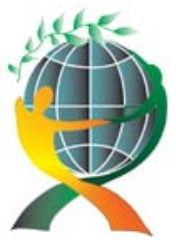

\author{
(online) $=$ ISSN $2285-3642$ \\ ISSN-L = $2285-3642$ \\ Journal of Economic Development, Environment and People \\ Volume 9, Issue 3, 2020
}

URL: http://jedep.spiruharet.ro

e-mail: office jedep@spiruharet.ro

[28] Cullen, J. M., Allwood, J. M., \& Bambach, M. D. (2012). Mapping the Global Flow of Steel: from Steel Making to End-Use Goods. Environmental Science \& Technology, 46(24), 13048-13055.

[29] Cutaia, L., \& Morabito, R. (2012). Ruolo Della Simbiosi Industriale Per la Green Economy. Energia, Ambiente e Innovazione.

[30] de Man, R., \& Friege, H. (2016). Circular Economy: European Policy on Shaky Ground. Waste Management \& Research, 34(2), 93-95.

[31] de Wit, M., Hoogzaad, J., Ramkumar, S., Friedl, H., \& Douma, A. (2018). The Circularity Gap Report-An Analysis of the Circular State of the Global Economy. Circle Economy. https://www.circularity-gap.world/

[32] European Commission (EC) (2010). Green Public Procurement. European Union, France. http://ec.europa.eu/environment/gpp/pdf/brochure.pdf

[33] EC (2011). Commission Staff Working Paper: Analysis Associated with the Roadmap to a Resource Efficient Europe, Part II. http://ec.europa.eu/environment/resource efficiency/pdf/working paper part2.pdf

[34] EC (2014). Moving towards a Circular Economy. http://ec.europa.eu/environment/circular-economy/

[35] EC (2015). Circular Economy Package: Questions \& Answers: MEMO/15/6204. http://europa.eu/rapid/pressrelease_MEMO-15-6204_en.htm

[36] EEA (2016). Report/ No. 2/2016: Circular Economy in Europe-Developing the Knowledge Base. Luxembourg: European Environmental Agency.

[37] Ellen MacArthur Foundation (EMF) (2012). Towards the Circular Economy: Economic and Business Rationale for an Accelerated Transition. Volume 1, Ellen MacArthur Foundation, Isle of Wight.

[38] EMF (2013). Towards the Circular Economy: Opportunities for the Consumer Goods Sector. Ellen MacArthur Foundation, Isle of Wight.

[39] EMF (2014). Towards the Circular Economy: Economic and Business Rationale for an Accelerated Transition. World Economic Forum, Geneva, Switzerland.

[40] EMF (2016). Circularity Indicators. World Economic Forum, Geneva, Switzerland. https://www.ellenmacarthurfoundation.org/programmes/insight/circularity-indicators

[41] EMF and McKinsey Center for Business and Environment (2015). Growth within: A Circular Economy Vision for a Competitive Europe. Ellen Mac Arthur Foundation and McKinsey Center for Business and Environment: Isle of Wight. https://www.ellenmacarthurfoundation.org/assets/downloads/publications/EllenMacArthurF oundation Growth-Within July15.pdf

[42] Erkman, S. (1997). Industrial Ecology: An Historical View. Journal of Cleaner Production, 5(1-2), 1-10.

[43] Erkman, S. (2001). Industrial Ecology: A New Perspective on the Future of the Industrial System. Swiss Medical Weekly, 131(37-38), 531-538.

[44] EU (2008). Directive 2008/98/EC of the European Parliament and of the Council of 19 November 2008 on Waste and Repealing Certain Directives. Official Journal of EU, L(312), 3-30.

[45] EU (2013). Decision No 1386/2013/EU of the European Parliament and of the Council of 20 November 2013 on a General Union Environment Programme to 2020. Living Well Within the Limits of Our Planet. http://eurlex.europa.eu/legalcontent/EN/TXT/PDF/?uri1CELEX:32013D1386\&from1EN

[46] EU-ASIA (2014). Eco-Cities. Sharing European and Asian Best Practices and Experiences. http://www.euasia.eu/publications/eco-cities/

[47] Frosch, R. A., \& Gallopoulos, N. E. (1989). Strategies for Manufacturing. Scientific American, 261(3), 144-152.

[48] Geissdoerfer, M., Savaget, P., Bocken, N. M. P., \& Hultink, E. J. (2017). The Circular Economy: A New Sustainability Paradigm? Journal of Cleaner Production, 143, 757-768. 


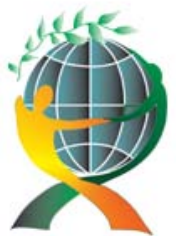

\author{
(online) $=$ ISSN $2285-3642$ \\ ISSN-L = $2285-3642$ \\ Journal of Economic Development, Environment and People \\ Volume 9 , Issue 3, 2020 \\ URL: http://jedep.spiruharet.ro \\ e-mail: office jedep@spiruharet.ro
}

[49] Ghisellini, P., Cialani, C., \& Ulgiati, S. (2016). A Review on Circular Economy: The Expected Transition to a Balanced Interplay of Environmental and Economic Systems, Journal of Cleaner Production, 114, 11-32.

[50] Geisendorf, S., \& Pietrulla, F. (2018). The Circular Economy and Circular Economic Concepts: A Literature Analysis and Redefinition. Thunderbird International Business Review, 60(5), 771-782.

[51] Geng, Y. Z., Xue, B., Dong, H., Fujita, T., \& Chiu, A. (2014). Emergy-based Assessment on Industrial Symbiosis: A Case Study on Shenyang Economic and Technological Development Zone. Environmental Science and Pollution Research, 21(23), 13572-13587.

[52] Genovese, A., Acquaye, A., Figueroa, A., \& Koh, S. (2017). Sustainable Supply Chain Management and the Transition towards a Circular Economy: Evidence and Some Applications. Omega, 66, 344-357.

[53] Gopal, N. M., Phebe, P., Kumar, E. V. S., \& Vani, B. K. K. (2014). National Seminar on Impact of Toxic Metals, Minerals and Solvents Leading to Environmental Pollution. Journal of Chemical and Pharmaceutical Sciences, 3, 96-99.

[54] Gu, L., \& Togay, O. (2016). Use of Recycled Plastics in Concrete: A Critical Review. Waste Management, 51, 19-42.

[55] Hawken, P., Lovins, A., \& Lovins, L. H. (2000). Natural Capitalism: Creating the Next Industrial Revolution. US Green Building Council: Washington, DC, USA.

[56] He, P., Lü, F., Zhang, H., \& Shao, L. (2013). Recent Developments in the Area of Waste as a Resource, with Particular Reference to the Circular Economy as a Guiding Principle, in Waste as a Resource 2013. In R. E. Hester \& R. M. Harrison (Eds.), Issues in Environmental Science and Technology No. 37. The Royal Society of Chemistry.

[57] Heshmati, A. (2015). A Review of the Circular Economy and Its Implementation. IZA Discussion Paper No. 9611, Sogang University and The Institute for the Study of Labor (IZA), Germany.

[58] Humphrey, A. (2005). SWOT Analysis for Management Consulting. SRI Alumni Association Newsletters, 1, 78. www.sri.com/sites/default/files/brochures/dec-05.pdf

[59] IES (2015). The Circular Economy in Japan. https://www.the-ies.org/analysis/circular-economy-japan

[60] IPCC (2014). Summary for Policymakers. In Climate Change 2014, Mitigation of Climate Change. Contribution of Working Group III to the Fifth Assessment Report of the Intergovernmental Panel on Climate Change, Geneva, Switzerland.

[61] lung, B., \& Levrat, E. (2014). Advanced Maintenance Services for Promoting Sustainability. Procedia CIRP, 22, 15-22.

[62] Jewell, C. (2015). Action Agenda for a Circular Economy Released at World Resource Forum. http://www.circulareconomyaustralia.com/blog/2015/6/3/action-agenda-for-a-circular-economyreleased-at-world-resources-forum

[63] Kay, T. (1994). Salvo in Germany-Reiner Pilz, p14 SalvoNEWS No. 99, 11 October 1994. https://www.salvoweb.com/files/sn99sm24y94tk181119.pdf

[64] Kirchherr, J., Reike, D., \& Hekkert, M. (2017). Conceptualizing the Circular Economy: An Analysis of 114 Definitions. Resources, Conservation and Recycling, 127, 221-232.

[65] Kuehr, R. (2012). Global e-waste Initiatives. In V. Goodship \& A. Stevels (Eds.), Waste Electrical and Electronic Equipment (WEEE) Handbook No. 30, in Woodhead Publishing Series in Electronic and Optical Materials, pp. 3-16. Woodhead Publishing Ltd.

[66] Legesse, B. (2014). Research Methods in Agribusiness and Value Chains. School of Agricultural Economics and Agribusiness, Haramaya University. 


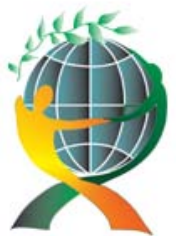

\author{
(online) $=$ ISSN $2285-3642$ \\ ISSN-L = $2285-3642$ \\ Journal of Economic Development, Environment and People \\ Volume 9, Issue 3, 2020
}

URL: http://jedep.spiruharet.ro

e-mail: office jedep@spiruharet.ro

[67] Lieder, M., \& Rashid, A. (2016). Towards Circular Economy Implementation: A Comprehensive Review in Context of Manufacturing Industry. Journal of Cleaner Production, 115, 36-51.

[68] Llanwarne, A. (2016). The Circular Economy: implications for the Environmental Movement. Report for Scottish Environment LINK.

[69] Lombardi, D. R., \& Laybourn, P. (2012). Redefining Industrial Symbiosis. Journal of Industrial Ecology, 16(1), 28-37.

[70] Lowe, E., Moran, S., \& Holmes, D. (1995). A Fieldbook for the Development of Ecoindustrial Parks. Report for the US Environmental Protection Agency (EPA). Indigo Development International, Oakland (CA).

[71] Lyle, J. T. (1994). Regenerative Design for Sustainable Development. John Wiley \& Sons, New York; Chichester.

[72] Marion, A. (2012). Chinese Eco-Cities: The Implementation of a New Economic Model? http://ecocitynotes.com/2012/06/chinese-eco-cities-neweconomic-model/

[73] Mathews, J. A., \& Tan, H. (2011). Progress towards a Circular Economy: The Drivers and Inhibitors of EcoIndustrial Initiative. Journal of Industrial Ecology, 15, 435-457.

[74] McDonough, W., \& Braungart, M. (2002). Cradle to Cradle: Remaking the Way We Make Things. New York: North Point Press.

[75] Merli, R., Preziosi, M., \& Acampora, A. (2017). How Do Scholars Approach the Circular Economy? A Systematic Literature Review. Journal of Cleaner Production, 178, 703-722.

[76] Mirabella, N., Castellani, V., \& Sala, S. (2014). Current Options for the Valorization of Food Manufacturing Waste: A Review. Journal of Cleaner Production, 65, 28-41.

[77] Mohajan, H. K. (2015). Planetary Boundaries Must not be Crossed for the Survival of Humanity. Journal of Environmental Treatment Techniques, 3(4), 184-200.

[78] Mohajan, H. K. (2019a). Knowledge Sharing among Employees in Organizations. Journal of Economic Development, Environment and People, 8(1), 52-61.

[79] Mohajan, H. K. (2019b). The First Industrial Revolution: Creation of a New Global Human Era. Journal of Social Sciences and Humanities, 5(4), 377-387.

[80] Mohajan, H. K. (2020). The Second Industrial Revolution has Brought Modern Social and Economic Developments. Journal of Social Sciences and Humanities, 6(1), 1-14.

[81] Murray, A., Skene, K., \& Haynes, K. (2015). The Circular Economy: An Interdisciplinary Exploration of the Concept and Application in a Global Context. Journal of Business Ethics, 140(3), 369-380.

[82] Natural Scotland (2013). Safeguarding Scotland's Resources: Blueprint for a More Resource Efficient and Circular Economy. Produced for the Scottish Government by APS Group, Scotland.

[83] Naustdalslid, J. (2014). Circular Economy in China: The Environmental Dimension of the Harmonious Society. International Journal of Sustainable Development \& World Ecology, 21(4), 303-313.

[84] Ness, D. (2008). Sustainable Urban Infrastructure in China: Towards a Factor 10 Improvement in Resource Productivity through Integrated Infrastructure System. International Journal of Sustainable Development \& World Ecology, 15, 288-301.

[85] Park, J. J., \& Chertow, M. (2014). Establishing and Testing the "Reuse Potential" Indicator for Managing Waste as Resources. Journal of Environmental Management, 137, 45-53.

[86] Park, J. J., Sarkis, J., \& Wu, Z. (2010). Creating Integrated Business and Environmental Value within the Context of China's Circular Economy and Ecological Modernization. Journal of Cleaner Production, 18, 1494-1501.

[87] Pauli, G. A. (2010). The Blue Economy: 10 Years, 100 Innovations, 100 Million Jobs. Taos NM, Paradigm Publications. 


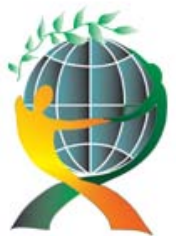

\author{
(online) $=$ ISSN $2285-3642$ \\ ISSN-L = $2285-3642$ \\ Journal of Economic Development, Environment and People \\ Volume 9 , Issue 3, 2020
}

URL: http://jedep.spiruharet.ro

e-mail: office jedep@spiruharet.ro

[88] Pearce, D. W., \& Turner, R. K. (1989). Economics of Natural Resources and the Environment. Hemel Hempstead, Harvester Wheatsheaf, London.

[89] Pesce, M., Tamai, I., Guo, D., Crittol, A., Brombal, D., Wang, X., Cheng, H., \& Marcomini, A. (2020). Circular Economy in China: Translating Principles into Practice. Sustainability, 12(832), 1-31.

[90] Pires, A., Martinho, G., Rodrigues, S., \& Gomes, M. A. (2019). Sustainable Solid Waste Collection and Management. Springer, Switzerland AG.

[91] Plastic Europe (2016). Plastics-The Facts 2016: An Analysis of European Plastics Production, Demand and Waste Data. Association of Plastics Manufacturers.

[92] Preston, F. (2012). A Global Redesign? Shaping the Circular Economy. Energy, Environment and Resource $\begin{array}{lll}\text { Governance, } & 2, & 1-20 .\end{array}$ https://www.chathamhouse.org/sites/files/chathamhouse/public/Research/Energy,\%20Environment\%20and \%20Development/bp0312_preston.pdf

[93] Redlich, T., \& Moritz, M. (2016). Bottom-up Economics. Foundations of a Theory of Distributed and Open Value. In Jan-Peter Ferdinand, Ulrich Petschow, \& Sascha Dickel (Eds.). The Decentralized and Networked Future of Value Creation: 3D Printing and its Implications for Society, pp. 27-57, Industry, and Sustainable Development, Springer.

[94] Reh, L. (2013). Process Engineering in Circular Economy. Particuology, 11, 119-133.

[95] Remenyi, D. S. J., Swartz, E., Money, A., \& Williams, B. (1998). Doing Research in Business and Management: An Introduction to Process and Method. SAGE Publications, London.

[96] Rizos, V., Tuokko, K., \& Behrens, A. (2017). The Circular Economy: A Review of Definitions, Processes and Impacts. CEPS Research Report No. 2017/08, CEPS, Brussels: Centre for European Policy Studies.

[97] Rossi, M., Germani, M., \& Zamagni, A. (2016). Review of Eco-design Methods and Tools: Barriers and Strategies for an Effective Implementation in Industrial Companies. Journal of Cleaner Production, 129, 361373.

[98] Sariatli, F. (2017). Linear Economy versus Circular Economy: A Comparative and Analyzer Study for Optimization of Economy for Sustainability. Visegrad Journal on Bioeconomy and Sustainable Development, 6(1), 31-34.

[99] Schwab, K. (Ed.) (2019). The Global Competitiveness Report. World Economic Forum. Geneva, Switzerland.

[100] Senge, P. M., Smith, B., Kruschwitz, N., Laur, J., \& Schley, S. (2010). The Necessary Revolution: How Individuals and Organizations are Working Together to Create a Sustainable World. Broadway Books, The Crown Publishing Group.

[101] Shen, L., Haufe, J., \& Patel, M. K. (2009). Product Overview and Market Projection of Emerging Bio-Based Plastics PRO-BIP 2009. Report for European Polysaccharide Network of Excellence (EPNOE) and European Bioplastics, Utrecht University, The Netherlands.

[102] Sitra (2016). Leading the Cycle: Finnish Road Map to a Circular Economy 2016-2025.

[103] Stahel, W. R. (2010). The Performance Economy (2 ${ }^{\text {nd }}$ Ed.). Palgrave Macmillan, Basingstoke, New York.

[104] Stahel, W. R., \& Reday, G. (1976). The Potential for Substituting Manpower for Energy. Research Contract No. 76/I3-V/343/78-EN, Programme of Research and Actions on the Development of the Labour Market. Report to the Commission of the European Communities.

[105] Steffen, W., Richardson, K., Rockström, J., Cornell, S. E., Fetzer, I., Bennett, E., Biggs, R., Carpenter, S. R., de Vries, W., de Wit, C. A., Folke, C., Gerten, D., Heinke, J., Mace, G. M., Persson, L. M., Ramanathan, V., Reyers, B., \& Sörlin, S. (2015). Planetary Boundaries: Guiding Human Development on a Changing Planet, 


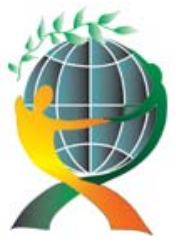

\author{
(online) $=$ ISSN $2285-3642$ \\ ISSN-L = $2285-3642$ \\ Journal of Economic Development, Environment and People \\ Volume 9, Issue 3, 2020
}

URL: http://jedep.spiruharet.ro

e-mail: office jedep@spiruharet.ro

Science, 347(6223): 1-17.

[106] STEP Initiative (2014). Solving the e-Waste Problem (STEP). White Paper, One Global Definition of eWaste. Bonn: STEP Initiative.

[107] Su, B., Heshmati, A., Geng, Y., \& Yu, X. (2013). A Review of the Circular Economy in China: Moving from Rethoric to Implementation. Journal of Cleaner Production, 42, 215-227.

[108] Sung, K., Cooper, T., \& Kettley, S. (2014). Individual Upcycling Practice: Exploring the Possible Determinants of Upcycling Based on a Literature Review. Sustainable Innovation 2014 Conference. Copenhagen.

[109] Tansel, B., \& Yildiz, B. S. (2011). Goal-based Waste Management Strategy to Reduce Persistence of Contaminants in Leachate at Municipal Solid Waste Landfills. Environment, Development and Sustainability, 13(5), 821-831.

[110] van Berkel, R., Fujita, T., Hashimoto, S., \& Geng, Y. (2009). Industrial and Urban Symbiosis in Japan: Analysis of the Eco-Town Program 1997-2006. Journal of Environmental Management, 90(3), 1544-1556.

[111] van Ewijk, S. (2018). Resource Efficiency and the Circular Economy: Concepts, Economic Benefits, Barriers, and Policies. The Department for Environment, Food \& Rural Affairs (Defra), UCL Institute for Sustainable Resources, London's Global University.

[112] Whalen, K. A., Berlin, C., Ekberg, J., Barletta, I., \& Hammersberg, P. (2018). 'All They Do is Win': Lessons Learned from Use of a Serious Game for Circular Economy Education. Resources, Conservation and Recycling, $135,335-345$.

[113] White, A. (1994). The Greening of Industrial Ecosystems, National Academy of Engineers. In B. R. Allenby \& D. J. Richards (Eds.), National Academy Press, Washington, DC.

[114] WHO (2018). Circular Economy and Health: Opportunities and Risks. World Health Organization.

[115] World Economic Forum (2018). Circular Economy in Cities: Evolving the Model for a Sustainable Urban Future. World Economic Forum, Geneva, Switzerland.

[116] Wrinkler, H. (2011). Closed-loop Production Systems-A Sustainable Supply Chain Approach. CIRP Journal of Manufacturing Science and Technology, 4(3), 243-246.

[117] Wysokinska, Z. (2016). The "New" Environmental Policy of the European Union: A Path to Development of a Circular Economy and Mitigation of the Negative Effects of Climate Change. Comparative Economic Research, 19(2), 57-73.

[118] Yuan, Z. W., Bi, J. \& Moriguichi, Y. (2006). The Circular Ecology: A New Development Strategy in China. Journal of Industrial Ecology, 10(1-2), 4-8.

[119] Zang, H. M. (2006). The Research on Theory of Governance and Application in the Circular Economy of Urban. PhD Dissertation, Tongji University, China.

[120] Zhong, S., \& Pearce, J. (2018). Tightening the Loop on the Circular Economy: Coupled Distributed Recycling and Manufacturing with Recyclebot and RepRap 3-D Printing. Resources, Conservation and Recycling, 128, 48-58.

[121] Zhuo, C., \& Levendis, Y. A. (2013). Upcycling Waste Plastics into Carbon Nanomaterials: A Review. Journal of Applied Polymer Science, 131(4), 1-14. 